\title{
Early high protein intake is associated with low mortality and energy overfeeding with high mortality in non-septic mechanically ventilated critically ill patients
}

Peter JM Weijs ${ }^{1,2,3^{*}}$, Wilhelmus GPM Looijaard ${ }^{1}$, Albertus Beishuizen ${ }^{1,4,5}$, Armand RJ Girbes ${ }^{1,4}$ and Heleen M Oudemans-van Straaten ${ }^{1,4}$

\begin{abstract}
Introduction: Early protein and energy feeding in critically ill patients is heavily debated and early protein feeding hardly studied.

Methods: A prospective database with mixed medical-surgical critically ill patients with prolonged mechanical ventilation (>72 hours) and measured energy expenditure was used in this study. Logistic regression analysis was used to analyse the relation between admission day-4 protein intake group (with cutoffs 0.8, 1.0, and $1.2 \mathrm{~g} / \mathrm{kg}$ ), energy overfeeding (ratio energy intake/measured energy expenditure $>1.1$ ), and admission diagnosis of sepsis with hospital mortality after adjustment for APACHE II (Acute Physiology and Chronic Health Evaluation II) score.

Results: A total of 843 patients were included. Of these, 117 had sepsis. Of the 736 non-septic patients 307 were overfed. Mean day-4 protein intake was $1.0 \mathrm{~g} / \mathrm{kg}$ pre-admission weight per day and hospital mortality was $36 \%$. In the total cohort, day- 4 protein intake group (odds ratio (OR) 0.85 ; $95 \%$ confidence interval (Cl) 0.73 to $0.99 ; P=0.047$ ), energy overfeeding (OR $1.62 ; 95 \% \mathrm{Cl} 1.07$ to $2.44 ; P=0.022$ ), and sepsis (OR $1.77 ; 95 \% \mathrm{Cl} 1.18$ to $2.65 ; P=0.005$ ) were independent risk factors for mortality besides APACHE II score. In patients with sepsis or energy overfeeding, day-4 protein intake was not associated with mortality. For non-septic, non-overfed patients $(n=419)$, mortality decreased with higher protein intake group: $37 \%$ for $<0.8 \mathrm{~g} / \mathrm{kg}, 35 \%$ for 0.8 to $1.0 \mathrm{~g} / \mathrm{kg}, 27 \%$ for 1.0 to $1.2 \mathrm{~g} / \mathrm{kg}$, and $19 \%$ for $\geq 1.2$ $\mathrm{g} / \mathrm{kg}(P=0.033)$. For these, a protein intake level of $\geq 1.2 \mathrm{~g} / \mathrm{kg}$ was significantly associated with lower mortality (OR 0.42 , $95 \% \mathrm{Cl} 0.21$ to $0.83, P=0.013)$.

Conclusions: In non-septic critically ill patients, early high protein intake was associated with lower mortality and early energy overfeeding with higher mortality. In septic patients early high protein intake had no beneficial effect on mortality.
\end{abstract}

\footnotetext{
*Correspondence: p.weijs@vumc.nl

Equal contributors

${ }^{1}$ Department of Intensive Care Medicine, VU University Medical Center

Amsterdam, De Boelelaan 1117, Amsterdam, The Netherlands

${ }^{2}$ Department of Nutrition and Dietetics, Internal Medicine, VU University

Medical Center Amsterdam, De Boelelaan 1117, 1081 HV Amsterdam, The

Netherlands

Full list of author information is available at the end of the article
} 


\section{Introduction}

Optimal nutrition in terms of supplied energy and protein intake, in critically ill patients remains a topic of discussion. Especially, energy intake during the early phase of critical illness has been addressed. Several studies have shown that early low-energy (trophic) feeding does not influence survival and might even be beneficial [1-4]. However, in the optimal-energy groups of these studies, energy targets were calculated and not measured. As early energy-overfeeding may be harmful [5], it cannot be excluded that energy overfeeding contributes to worse outcome. Up to now, there have been no randomised studies investigating early protein-feeding per se. Observational studies have shown that protein intake according to current guidelines, 1.2 to $1.5 \mathrm{~g} / \mathrm{kg} /$ day, is related to lower mortality [6-9]. Recent expert opinion even recommends more than $1.5 \mathrm{~g} / \mathrm{kg} /$ day [10]. However, controversial results and hypotheses have been reported recently. In post-mortem muscle biopsies (12 patients), impaired autophagy correlated with the amount of infused amino acids [11]. Second, in a post-hoc analysis of the EPaNIC trial, the cumulative amount of protein/amino acid early during ICU stay was associated with delayed recovery [12]. Recently, a small observational study, including 50\% patients with sepsis, reported a positive association between the change in muscle cross-sectional area in the first 1.5 weeks of ICU stay and protein intake, indicating more pronounced muscle wasting in the case of higher protein intake [13].

A proposed mechanism of the observed negative effect of protein is that early protein-feeding inhibits autophagy $[11,14]$. Autophagy provides a functional role in sepsis by promoting intracellular bacterial clearance [15]. Thus, early high-protein intake may especially be harmful in sepsis. In most studies, protein is provided in a fixed proportion to energy. We have been using several nutritional formulas with different protein/energy ratios and an algorithm to calculate both energy- and protein targets [16]. This allows us to study the effect of protein intake independent of energy intake. We previously found that mortality was lower in patients reaching both the energy and the protein targets, in contrast to energy targets alone. In that study, we analyzed the cumulative protein and energy provision over the entire period of mechanical ventilation, but in the present study we present new data on early protein- and energy-feeding [7].

The hypotheses underlying the present study are: 1) early protein intake of more than $1.2 \mathrm{~g} / \mathrm{kg}$ according to ESPEN guidelines is beneficial [17]; 2) early high-protein intake could be harmful in patients with sepsis, possibly because of inhibition of autophagy; 3) early energy overfeeding is harmful and therefore might obscure the beneficial effect of early high-protein intake. To explore these hypotheses, we performed a post-hoc analysis with new prospective observational data on early (day 4) protein- and energy-intake and their association with hospital mortality, accounting for sepsis.

\section{Methods}

This is a post-hoc analysis of new (unpublished) prospective observational data in a mixed medical-surgical ICU in a university hospital. Between August 2004 and March 2010, hemodynamically stable mechanically ventilated critically ill patients were included on days 3 to 5 when the predicted period of artificial nutrition was at least 5 to 7 additional days. Additional inclusion criteria were indirect calorimetry performed during ICU admission, age over 18 years, and first ICU admission. Exclusion criteria were inspired oxygen fraction $\left(\mathrm{FiO}_{2}\right)>0.6$, air leakage, and unavailable metabolic monitor data.

The study was approved by the ethics committee of the VU University Medical Center Amsterdam. Informed consent was waived because the study used variables routinely collected in clinical practice.

Early enteral nutrition (EN) was initiated in hemodynamically stable patients within the first 24 hours of ICU admission according to our protocol. The preferable route of administration was enteral. Parenteral nutrition (PN) was provided only when the gut failed (fistulas, short bowel, or obstruction) and was not given as parenteral supplementation to inadequate amounts of EN in the first week of nutritional therapy.

Energy requirements were initially calculated using the Harris and Benedict formula with an added $10 \%$ for activity and 20\% for stress [7] and adjusted when indirect calorimetry was performed. Indirect calorimetry was performed using a Deltatracmonitor (Deltatrac MBM-100 Metabolic Monitor, Datex-Engstrom Division, Instrumentation Corp., Helsinki, Finland). Measurements were performed while patients were hemodynamically stable and calm, and ventilation allowed connection of the device. Enteral nutrition was deliberately continued during indirect calorimetry in order to assess total energy expenditure [18]. The new energy target was the measured energy expenditure with an added $10 \%$ for activity.

Protein was provided with a target of 1.2 to $1.5 \mathrm{~g} / \mathrm{kg}$ pre-admission body weight. Protein intake was adjusted for body mass index (BMI) $<20 \mathrm{~kg} / \mathrm{m}^{2}$ to weight at BMI $20 \mathrm{~kg} / \mathrm{m}^{2}$ and for BMI $>30 \mathrm{~kg} / \mathrm{m}^{2}$ to weight at BMI 27.5 $\mathrm{kg} / \mathrm{m}^{2}$ [19]. Protein provision was not reduced in case of renal failure, neither was it increased during continuous renal replacement therapy (CRRT).

The algorithm was used to determine the optimal nutritional formula and amount needed to meet both protein and energy requirements and accordingly indicated by the patient data management system (PDMS, Metavision, IMD-soft, Tel-Aviv, Israel) in a dedicated spreadsheet [16]. The specific formulas were chosen for their different 
energy/protein ratios (Nutrison standard and Nutrison Protein PlusNutricia, Zoetermeer, Netherlands), and Promote (Abbott Nutrition, Abbott Park, IL, USA) [7].

Patient data, indirect calorimetry measurements, type of nutrition, pump settings, and protein and energy intake data from all sources including fluids and drugs, were hourly entered in the PDMS allowing accurate calculation of protein and energy intake. Protein and energy intake on day 4 was chosen as indicators of early intake, in line with the Dutch national nutritional performance indicator [20].

Energy intake on day 4 is expressed as the ratio of early (day 4) energy intake versus measured energy expenditure by indirect calorimetry. Energy overfeeding was defined by a ratio of $>1.1$ (yes/no). Protein provision on day 4 is expressed in $\mathrm{g}$ per $\mathrm{kg}$ pre-admission body weight. Allocation to septic and non-septic groups was based on the presence of severe sepsis or septic shock on ICU admission, using Surviving Sepsis Campaign guidelines criteria $[21,22]$.

\section{Statistical analysis}

Descriptive data are reported as mean and SD, median and interquartile range (for skewed distributions) or frequency and percentage. The Fisher exact test was used to compare categorical variables, and the chi square test was used to compare protein intake groups. Logistic regression analysis was performed with hospital mortality as the outcome variable and early protein intake group (with cutoffs of $0.8,1.0$, and $1.2 \mathrm{~g} / \mathrm{kg}$ ), early energy overfeeding (yes/no), and sepsis (yes/no) as independent variables, adjusted for acute physiology and chronic health evaluation (APACHE) II score. Separate analyses were performed for the cohorts with sepsis on ICU admission, with overfeeding, and finally non-septic non-overfed patients. Additionally a sensitivity analysis was performed with patients receiving at least $50 \%$ of measured energy expenditure. SPSS 20 (SPSS Inc., Chicago, IL, USA) was used for statistical analysis. A $P$-value $<0.05$ was considered statistically significant.

\section{Results}

During the study period, 4,803 patients were admitted to the ICU; 1,720 patients remained more than 3 days in the unit and 843 fulfilled the inclusion criteria (Figure 1). Nutrition during ICU stay was fully enteral in 618 (73\%) and fully parenteral in 7 (1\%) patients or mixed in 218 (26\%) patients. Energy expenditure was measured median 5, mean of 7.2 9.4 days after admission.

Overall $(n=843)$ mean energy intake at day 4 was $1,710699 \mathrm{kcal}$ corresponding to $95 \%$ of measured energy expenditure (Table 1). Energy from sources other than nutrition (glucose and propofol) comprised median $132 \mathrm{kcal} /$ day, accounting for $7.9 \%$ of the total energy intake; $10.1 \%$ in the non-overfed versus $6.4 \%$ in the overfed cohort $(P<0.001)$.

Overall $(n=843)$ mean protein intake at day 4 was $0.970 .49 \mathrm{~g} / \mathrm{kg}$. When protein intake groups $(<0.8,0.8$ to $<1.0,1.0$ to $<1.2$, and $\geq 1.2 \mathrm{~g} / \mathrm{kg}$ ) were considered, and there was no difference in mortality; 37.6\%, 35.4\%, $35.4 \%$, and $35.1 \%$ respectively, $P=0.930$. To test the hypothesis that early protein intake has different effects in septic and non-septic patients, we analysed septic and non-septic patients separately.

\section{Septic patients}

The septic cohort consisted of 117 patients (14\%) admitted with sepsis. Hospital mortality was significantly higher in septic patients than in non-septic patients (48.7\% versus $33.9 \%, P=0.003$; Figure 2 ). The APACHE II score was higher as well $(25.4$ versus $22.6, P<0.001)$ (Table 1). Logistic regression analysis showed that mortality was not related to protein intake, energy overfeeding or APACHE II score in the septic cohort (Table 2).

\section{Non-septic overfed and non-overfed patients}

Patient characteristics and nutritional data of non-septic overfed patients $(n=307)$ and non-septic non-overfed patients $(n=419)$ are shown in Table 1 . In the non-septic cohort hospital mortality was not significantly higher in the day-4 overfed patients than in the non-overfed group (36.4\% versus $32.1 \%, P=0.234$ ), the APACHE II scores were similar and energy intake in the non-overfed group was only $71 \%$ of measured EE. Figure 3 shows the cumulative energy deficit over the first 4 days of ICU stay $(\mathrm{n}=726)$, with worst hospital mortality outcome in the overfed group $(P=0.053)$.

In this non-septic cohort $(n=726)$, logistic regression analysis demonstrated that the day-4 protein intake group (odds ratio $(\mathrm{OR})=0.80,95 \% \mathrm{CI} 0.67,0.95, P=0.011$ ), day 4 overfeeding $(\mathrm{OR}=1.89$, 95\% CI 1.19, 3.02, $P=0.007)$, and APACHE II score $(\mathrm{OR}=1.04,95 \%$ CI 1.01, 1.06, $P=0.001$ ) had significant independent impact on mortality (Table 2 ). Thus, high day-4 protein intake was related to lower mortality in non-septic patients, while day-4 overfeeding and higher APACHE II score were related to higher mortality. The day-4 protein intake group was not related to mortality in the non-septic overfed group (Table 2).

\section{Non-septic and non-overfed patients}

In patients who were not septic and not overfed $(n=419)$, the higher protein intake group was associated with lower mortality (Table 3). Hospital mortality was 36.8\%, 35.0\%, $26.5 \%$, and $19.1 \%$ for the $<0.8,0.8$ to $<1.0,1.0$ to- $<1.2$, and $\geq 1.2 \mathrm{~g} / \mathrm{kg}$ protein-intake groups respectively $(P=0.033)$. Hospital mortality was $34.5 \%$ for day- 4 protein intake $<1.2$ $\mathrm{g} / \mathrm{kg}$ versus $19.1 \%$ for day-4 protein intake $\geq 1.2 \mathrm{~g} / \mathrm{kg}$ 


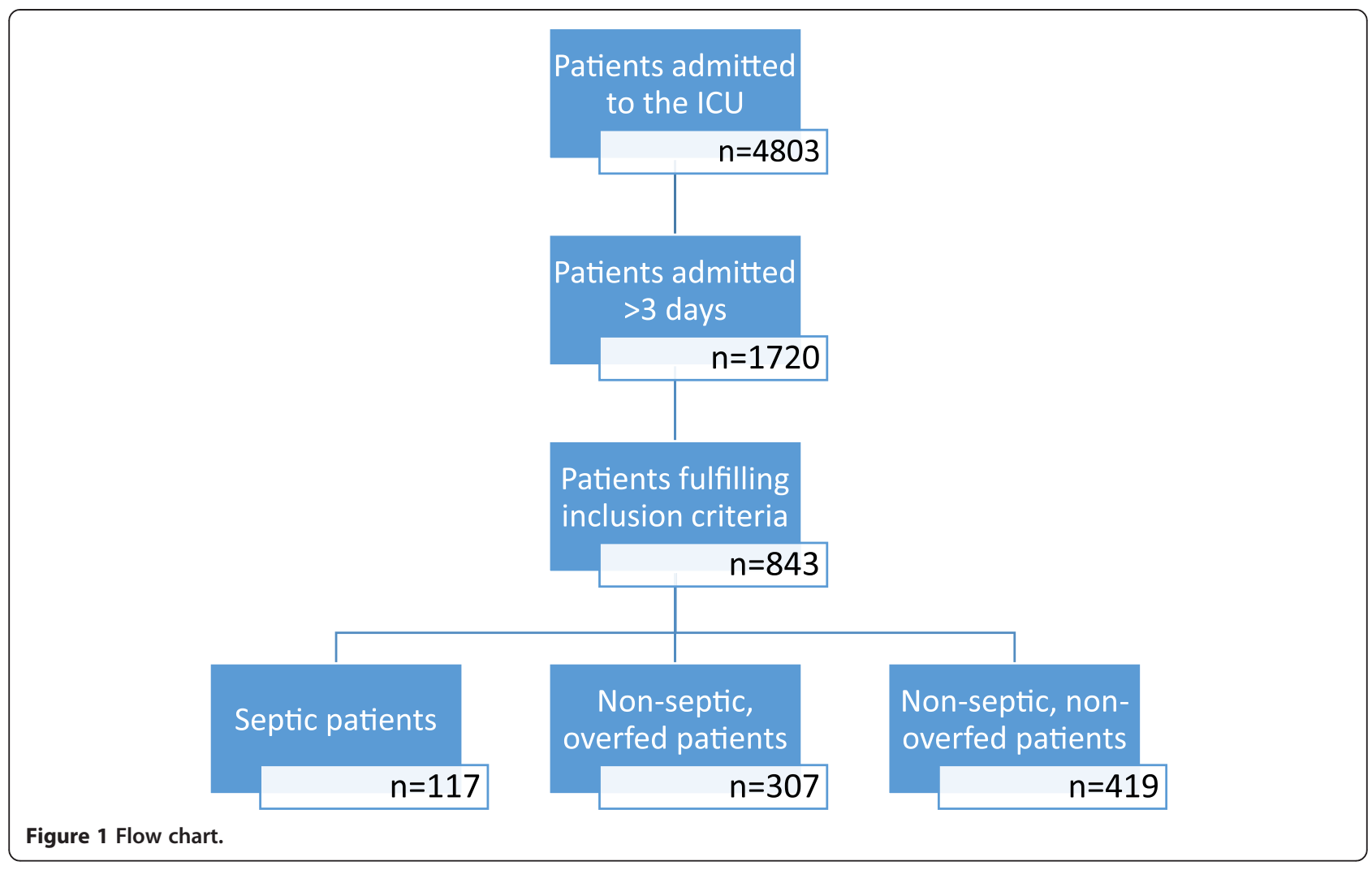

$(P=0.015$; Figure 4$)$. Regression analysis with dummies for protein intake groups showed that the effect of protein was only significant at a protein intake level of $\geq 1.2$ $\mathrm{g} / \mathrm{kg}(\mathrm{OR}=0.42,95 \%$ CI $0.21,0.83, P=0.013)$.

Adjustment for patients with any use of parenteral nutrition did not change the results. BMI was not a significant predictor of mortality either in the whole group or in subgroup analysis.

\section{Possible underfeeding effect}

To further explore whether the higher mortality in the low protein-intake group in non-septic non-overfed patients was caused by energy underfeeding rather than low protein feeding, a sensitivity analysis on energy intake was performed. In the $<0.8 \mathrm{~g} / \mathrm{kg}$ protein group, 108 out of 223 patients were seriously underfed (defined as $<50 \%$ of measured energy expenditure (EE)). Mortality was $37.2 \%$ including all patients in the $<0.8 \mathrm{~g} / \mathrm{kg}$ protein group, and $40.8 \%$ excluding the patients with $<0.8 \mathrm{~g} / \mathrm{kg}$ protein and an energy intake of $<50 \%$ of measured EE. Thus, the contrast between the $<0.8 \mathrm{~g} / \mathrm{kg}$ group and the $>1.2 \mathrm{~g} / \mathrm{kg}$ group increased when the seriously underfed group in terms of EE was excluded (40.8\% versus $19.4 \%$, $P=0.012)$. In the $\geq 1.2 \mathrm{~g} / \mathrm{kg}$-protein group none of the patients were energy underfed. When comparing the $\geq 1.2 \mathrm{~g} / \mathrm{kg}$-protein group to the $<0.8 \mathrm{~g} / \mathrm{kg}$-protein group, the OR for mortality for the $\geq 1.2 \mathrm{~g} / \mathrm{kg}$-protein group was $0.38(95 \%$ CI $0.18,0.81)$ in those receiving $>50 \%$ of $\mathrm{EE}$, and $0.22(95 \% \mathrm{CI} 0.06,0.77)$ in those receiving optimal energy intake (90-100\% of EE).

\section{Discussion}

This post-hoc observational study in critically ill patients undergoing prolonged mechanical ventilation shows that high early-protein intake (defined as intake at day 4) is associated with lower hospital mortality and early energy overfeeding with higher mortality, independent of APACHE II score and the presence of sepsis. A benefit of early high-protein intake was only found in the nonseptic and non-overfed patients and not in patients admitted with sepsis and in those with early energy overfeeding. The lowest mortality was found in non-septic patients without overfeeding receiving $>1.2 \mathrm{~g} / \mathrm{kg}$ protein (pre-admission weight). Thus, our findings justify the current recommendation on protein intake in patients without sepsis being at least $1.2 \mathrm{~g} / \mathrm{kg}$ as early as day 4 of ICU admission [17]. They also stress the importance of measuring EE to prevent early overfeeding. However, for septic patients a clear protein recommendation cannot be given based on this study.

\section{Protein}

Up to now, early protein feeding per se has not been evaluated in randomised studies. In the previous analysis 
Table 1 Patient characteristics and outcome

\begin{tabular}{|c|c|c|c|c|c|c|c|c|c|}
\hline & \multirow{2}{*}{\multicolumn{2}{|c|}{$\begin{array}{l}\text { Septic patients } \\
\mathrm{n}=117\end{array}$}} & \multirow{2}{*}{\multicolumn{2}{|c|}{$\begin{array}{l}\text { Non-septic overfed } \\
\text { patients } \\
\mathrm{n}=307 \\
\end{array}$}} & \multirow{2}{*}{\multicolumn{2}{|c|}{$\begin{array}{l}\text { Non-septic non-overfed } \\
\text { patients } \\
\mathrm{n}=419 \\
\end{array}$}} & \multirow{2}{*}{\multicolumn{2}{|c|}{$\begin{array}{l}\text { All patients } \\
\mathrm{n}=843\end{array}$}} & \multirow{3}{*}{$\begin{array}{l}\text { Analysis of variance, } \\
\text { Kruskal-Wallis test or } \\
\text { chi squared test, } P \text {-value }\end{array}$} \\
\hline & & & & & & & & & \\
\hline & Mean & SD & Mean & SD & Mean & SD & Mean & SD & \\
\hline Male gender, \% & \multicolumn{2}{|l|}{64.1} & \multicolumn{2}{|l|}{60.3} & \multicolumn{2}{|l|}{64.9} & \multicolumn{2}{|l|}{63.1} & 0.426 \\
\hline Age, y & 64.2 & 14.2 & 61.3 & 17.1 & 63.2 & 16.4 & 62.6 & 16.4 & 0.172 \\
\hline Weight, kg & $75.6^{\mathrm{a}, \mathrm{b}}$ & 20.3 & $74.2^{\mathrm{a}}$ & 18.4 & $78.4^{\mathrm{b}}$ & 16.7 & 76.5 & 18.0 & 0.006 \\
\hline Height, cm & 172 & 10.7 & 172 & 9.7 & 173 & 9.6 & 172 & 9.8 & 0.804 \\
\hline Body mass index, kg/m2 & $25.4^{\mathrm{a}, \mathrm{b}}$ & 5.8 & $25.0^{\mathrm{a}}$ & 5.8 & $26.3^{b}$ & 5.2 & 25.7 & 5.5 & 0.006 \\
\hline Body mass index $<18.5, \%$ & \multicolumn{2}{|l|}{6.8} & \multicolumn{2}{|l|}{7.2} & \multicolumn{2}{|l|}{2.1} & \multicolumn{2}{|l|}{4.6} & \\
\hline Body mass index $>30, \%$ & \multicolumn{2}{|l|}{12.8} & \multicolumn{2}{|l|}{12.7} & \multicolumn{2}{|l|}{18.5} & \multicolumn{2}{|l|}{15.3} & \\
\hline APACHE \| score & $25.4^{\mathrm{a}}$ & 8.3 & $22.5^{\mathrm{b}}$ & 7.5 & $17.9^{\mathrm{b}}$ & 8.1 & 23.0 & 7.9 & 0.001 \\
\hline Respiratory rate, /minute ${ }^{W}$ & 22 & 6 & 21 & 7 & 21 & 7 & 21 & 7 & 0.188 \\
\hline $\mathrm{VO}_{2}, \mathrm{ml} /$ minute $^{\mathrm{W}}$ & $264^{a, b}$ & 69 & $254^{\mathrm{a}}$ & 51 & $278^{b}$ & 60 & 268 & 60 & $<0.001$ \\
\hline $\mathrm{VCO}_{2}, \mathrm{ml} /$ minute $^{\mathrm{W}}$ & $227^{a, b}$ & 56 & $224^{\mathrm{a}}$ & 42 & $233^{b}$ & 51 & 229 & 49 & 0.036 \\
\hline Respiratory quotient ${ }^{\mathrm{W}}$ & $0.87^{a, b}$ & 0.10 & $0.89^{\mathrm{a}}$ & 0.11 & $0.84^{\mathrm{b}}$ & 0.10 & 0.86 & 0.11 & $<0.001$ \\
\hline $\mathrm{FiO}_{2}, \% \mathrm{~W}, \mathrm{z}$ & 40 & 40 to 45 & 40 & 40 to 45 & 40 & 40 to 45 & 40 & 40 to 45 & 0.075 \\
\hline Measured $\mathrm{EE}^{\times}, \mathrm{kcal} / \mathrm{d}$ & $1,808^{a, b}$ & 359 & $1,776^{\mathrm{a}}$ & 318 & $1,886_{b}$ & 347 & 1,835 & 342 & $<0.001$ \\
\hline Estimated $\mathrm{EE}^{\mathrm{y}}, \mathrm{kcal} / \mathrm{d}$ & 1,991 & 415 & 1,983 & 365 & 2,049 & 368 & 2,017 & 375 & 0.048 \\
\hline Day 4 energy, kcal/d & $1,673^{\mathrm{a}}$ & 703 & $2,234^{b}$ & 430 & $1,337^{c}$ & 608 & 1,710 & 699 & $<0.001$ \\
\hline Day 4 intake/measuredEE & $0.95^{\mathrm{a}}$ & 0.40 & $1.27^{b}$ & 0.18 & $0.71^{c}$ & 0.30 & 0.95 & 0.38 & $<0.001$ \\
\hline Day 4 protein, $\mathrm{g} / \mathrm{kg}$ & $1.00^{\mathrm{a}}$ & 0.53 & $1.33^{b}$ & 0.28 & $0.69^{c}$ & 0.43 & 0.97 & 0.49 & $<0.001$ \\
\hline Length of ventilation ${ }^{z}, d$ & 18 & 12 to 29 & 16 & 10 to 28 & 17 & 10 to 28 & 17 & 10 to 28 & 0.495 \\
\hline Length of ICU stay ${ }^{2}, d$ & 22 & 14 to 34 & 19 & 12 to 31 & 20 & 12 to 31 & 20 & 12 to 31 & 0.516 \\
\hline Length of hospital stay ${ }^{2}, d$ & 32 & 21 to 55 & 37 & 22 to 59 & 35 & 21 to 59 & 35 & 21 to 59 & 0.544 \\
\hline ICU mortality, \% & 26.5 & & 20.8 & & 18.6 & & 20.5 & & 0.173 \\
\hline Hospital mortality, \% & 48.7 & & 36.5 & & 32.0 & & 35.9 & & 0.004 \\
\hline
\end{tabular}

$a, b, c$ Values in the same row not sharing the same letter are significantly different at $P<0.05$ in a post-hoc Bonferroni analysis or pairwise comparison on analysis of variance or Kruskal-Wallis test. WValue at time of energy expenditure measurement. ${ }^{\mathrm{x} E n e r g y ~ t a r g e t ~ d e f i n e d ~ b y ~ i n d i r e c t ~ c a l o r i m e t r y . ~}{ }^{\mathrm{y}}$ Energy target defined by Harris Benedict formula $+30 \%$. ${ }^{\mathrm{z}}$ Non-normally distributed; data presented as median and $25^{\text {th }}$ to $75^{\text {th }}$ percentiles. $P$-values in bold indicate a significant test result. $\mathrm{APACHE}$, acute physiology and chronic health evaluation; $\mathrm{VO}_{2}$, oxygen uptake; $\mathrm{VCO}_{2}$, carbon dioxide elimination; $\mathrm{FiO}_{2}$, inspired oxygen fraction; $\mathrm{EE}$, energy expenditure.

of this patient cohort we showed that a protein intake of more than $1.2 \mathrm{~g} / \mathrm{kg}$ over the whole period of mechanical ventilation was associated with lower mortality [6,7]. Reaching energy targets alone was not sufficient. These results were confirmed and extended by the observational study of Allingstrup et al., showing a decrease in mortality with increasing protein intake up to $1.5 \mathrm{~g} / \mathrm{kg}$ [8].

A recent secondary analysis of an observational study including 2,270 septic ventilated medical patients receiving enteral nutrition with a mean of $14.5 \mathrm{kcal} / \mathrm{kg}$ and 0.7 $\mathrm{g} / \mathrm{kg}$ protein per day found that both an increase of $1,000 \mathrm{kcal}$ and of $30 \mathrm{~g}$ protein per day, thus a delivery closer to recommended protein intake, was associated with reduced mortality [9]. This study covered the mean energy and protein intake for a maximum of 12 days or until death after ICU discharge, and did not address intake as early as day 4 . Of note, mean protein and energy intakes in this septic cohort were lower than in our (septic) cohort, and protein and energy intake were related.

However, results of randomised studies are confusing, because early underfeeding, which implies low protein intake, appears not to increase mortality $[1,4]$. Supplemental PN was even associated with an increased infection rate and higher duration of mechanical ventilation and renal replacement therapy in the largest trial [1]. An explanation could be that nutrition inhibits autophagy [23]. Autophagy is considered a housekeeping system to remove dysfunctional and toxic proteins and complete cellular structures [11,23], and the degradation products subsequently provide nutritional substrate. In a sub-study of the EPanic trial, late PN was associated with reduced muscle weakness and more efficient autophagic control of muscle fibres [24], although the final muscle weakness assessment was not different. Which nutritional component 


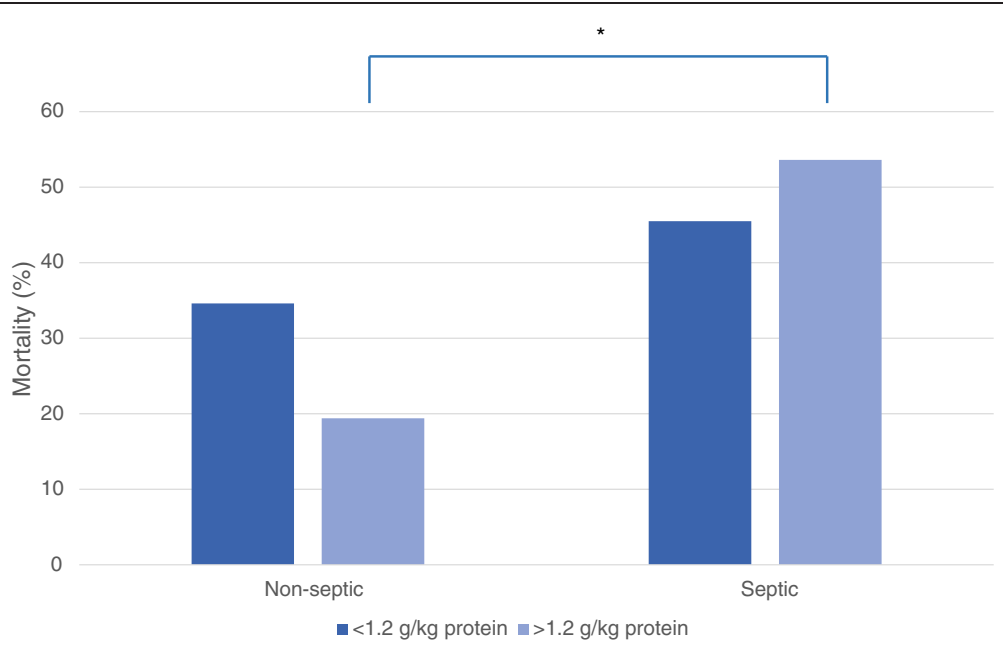

Figure 2 Hospital mortality for septic and non-septic patients with protein intake higher and lower than $1.2 \mathrm{~g} / \mathrm{kg} .{ }^{*} P=0.003$.

contributes to inhibition of autophagy most is as yet unknown. However, some studies suggest that protein might be more important than glucose [11,12], although Casaer et al. did not adjust for energy intake [12]. This suggestion seems to contradict our finding that early high-protein intake was associated with lower mortality. However, our study also shows that in the septic cohort early highprotein intake was not associated with lower mortality,

\section{Table 2 Logistic regression analysis}

\begin{tabular}{|c|c|c|c|}
\hline & $\begin{array}{l}\text { Odds } \\
\text { ratio }\end{array}$ & $95 \% \mathrm{Cl}$ & $P$-value \\
\hline \multicolumn{4}{|l|}{ All patients $(n=843)$} \\
\hline Protein intake group ${ }^{a}$ & 0.85 & $0.73,0.99$ & 0.047 \\
\hline Energy overfeeding (yes/no) & 1.62 & $1.07,2.44$ & 0.022 \\
\hline Sepsis (yes/no) & 1.77 & $1.18,2.65$ & 0.005 \\
\hline APACHE II score & 1.04 & $1.02,1.05$ & $<0.001$ \\
\hline \multicolumn{4}{|l|}{ Septic patients $(n=117)$} \\
\hline Protein intake group ${ }^{a}$ & 1.15 & $0.80,1.66$ & 0.460 \\
\hline Energy overfeeding (yes/no) & 0.82 & $0.35,2.29$ & 0.821 \\
\hline APACHE \| score & 1.03 & $0.98,1.08$ & 0.208 \\
\hline \multicolumn{4}{|l|}{ Non-septic patients $(n=726)$} \\
\hline Protein intake group ${ }^{a}$ & 0.80 & $0.67,0.95$ & 0.011 \\
\hline Energy overfeeding (yes/no) & 1.89 & $1.19,3.02$ & 0.007 \\
\hline APACHE II score & 1.04 & $1.01,1.06$ & 0.001 \\
\hline \multicolumn{4}{|c|}{ Non-septic overfed patients $(n=307)$} \\
\hline Protein intake group ${ }^{a}$ & 0.91 & $0.59,1.40$ & 0.666 \\
\hline APACHE II score & 1.04 & $1.00,1.07$ & 0.029 \\
\hline \multicolumn{4}{|c|}{ Non-septic non-overfed patients $(n=419)$} \\
\hline Protein intake group ${ }^{a}$ & 0.77 & $0.63,0.93$ & 0.008 \\
\hline APACHE II score & 1.03 & $1.01,1.06$ & 0.013 \\
\hline
\end{tabular}

Protein intake groups were $<0.8,0.8$ to $<1.0,1.0$ to $<1.2$, and $\geq 1.2 \mathrm{~g} / \mathrm{kg}$. $P$-values in bold indicate a significant test result. APACHE, acute physiology and chronic health evaluation. which is in line with the patient group of Puthucheary et al. [13] of which half was admitted with sepsis. We hypothesized that septic patients could behave differently because autophagy is also used to degrade intracellular micro-organisms [25]. Thus, autophagy provides a functional role in sepsis by promoting intracellular microbial clearance. Furthermore, in a recent study in critically ill septic patients receiving $\mathrm{PN}$, muscle protein synthesis was normal, but protein breakdown was increased up to $260 \%$ compared to healthy controls [26]. Apparently, feeding could not suppress increased protein breakdown in these septic patients. In favour of protein are the randomised trials on supplemental parenteral nutrition that administered a higher amount of protein [2,27], measured energy expenditure [27], and found a positive impact of supplemental parenteral nutrition on clinical outcomes [2,27]. Taken together there appears to be a delicate balance in the critically ill patient, and timing and dosing of protein and energy in specific disease groups will have to be addressed in future randomised studies.

\section{Overfeeding}

Our study also showed that day-4 energy overfeeding was harmful. Overfeeding was defined as an energy intake of more than $110 \%$ of measured EE. Forty-one percent of our patients appeared to be overfed on day 4 . This means that a standard prescription of estimated energy requirement by Harris-Benedict equation plus $30 \%$ is an inaccurate predictor of energy requirements in ICU patients, as has been reported before [5,28,29]. Although newer formulas might be more accurate [30], measurement of EE by indirect calorimetry remains the most appropriate tool. However, even when knowing actual EE, it is not known whether energy supply should cover the full equivalent of energy expenditure during the first days of critical illness, because nutrition cannot suppress 


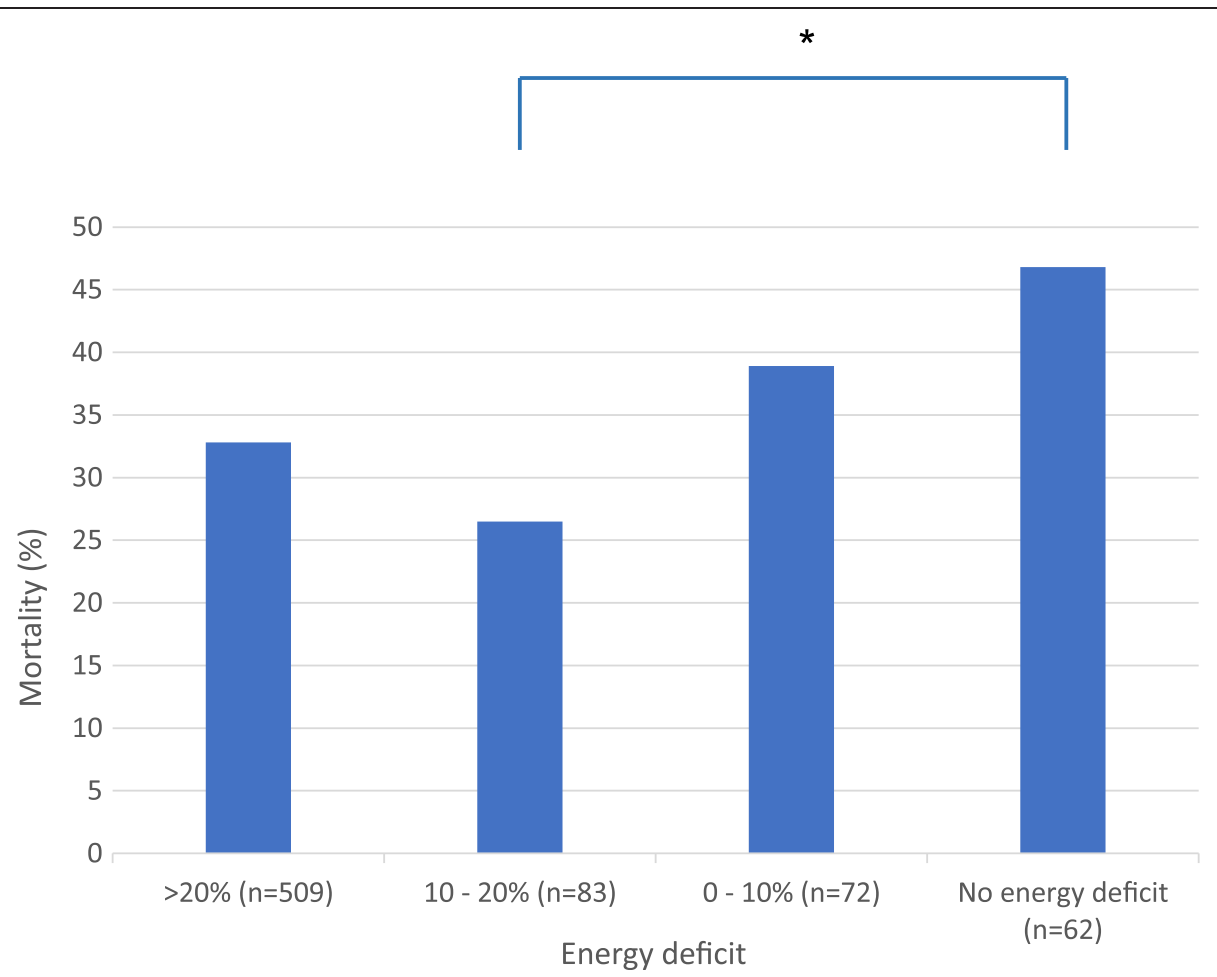

Figure 3 Hospital mortality for cumulative energy deficit over the first 4 days of ICU stay for non-septic patients $(n=726 ; P=0.053)$. Reference is the measured resting energy expenditure of the patient. ${ }^{*} P=0.012$.

early endogenous glucose production which may provide more than $50 \%$ of energy expenditure [5]. Figure 3 suggests that mild (10 to $20 \%$ ) underfeeding of energy in the early period of ICU stay might be beneficial. Of note, the increased rate of infections and longer duration of mechanical ventilation and renal replacement therapy found in the EPaNIC trial [1] could partially be explained by a component of overfeeding, because energy needs were not measured but calculated, and rather high energy targets were attained. A smaller study applying calorimetry-tailored nutrition found a trend to lower mortality rate in the supplemental PN group, but also an increased infection rate and longer ventilation and ICU stay [31]. Remarkably, both energy and protein intake were higher in the calorimetry-tailored group. Furthermore, the Swiss trial observed fewer infections in the group receiving supplemental PN from day 4 [27]. Energy intake was tailored by calorimetry and protein intake was higher than in the EPaNIC study. Finally, in the Australian trial, supplemental PN from day 1 provided no effect on mortality or infection rate, but decreased muscle wasting, ventilator duration, and improved quality of life [2]. Thus, in the last three trials, a higher protein and energy intake was beneficial. Whether in favour of targeted feeding or not, these studies were not designed to investigate early protein-targeted feeding and in some of these studies some of the patients were likely overfed [32].

Our study has several limitations, in particular its observational design. A lower early-protein intake may reflect a higher severity of disease. However, protein intake remained a predictor of mortality, independent of APACHE II score, the standard estimate of mortality in critically ill patients. Also, an improved energy intake but with insufficient protein ( 0.8 to $1.2 \mathrm{~g} / \mathrm{kg}$ ) was not associated with lower mortality. We previously showed that the application of our nutritional algorithm improved adequate protein supply at day 4 from about $30 \%$ to almost $60 \%$. However, despite our algorithm, not all patients received adequate protein intake. Furthermore, estimating EE using the old Harris-Benedict equation $+30 \%$ appears to be associated with significant overfeeding. In addition, the measurement of EE was generally measured after day 4. This means that overfeeding could have been ongoing for a couple of days before it was noticed and corrected. Unfortunately, in clinical practice daily measurement of EE is not feasible. Finally, the number of septic patients was relatively low, but proportional to the admission pattern of the unit.

A strong point of our study is the distinction between patients with and without early energy overfeeding. The negative effect of early overfeeding on patient outcome 
Table 3 Patient characteristics and outcome in non-septic, non-overfed patients

\begin{tabular}{|c|c|c|c|c|c|c|c|c|c|c|c|}
\hline & \multirow{2}{*}{\multicolumn{2}{|c|}{$\begin{array}{l}<0.8 \mathrm{~g} / \mathrm{kg} \\
\mathrm{n}=223\end{array}$}} & \multirow{2}{*}{\multicolumn{2}{|c|}{$\begin{array}{l}0.8 \text { to }<1.0 \mathrm{~g} / \mathrm{kg} \\
\mathrm{n}=60\end{array}$}} & \multirow{2}{*}{\multicolumn{2}{|c|}{$\begin{array}{l}1.0 \text { to }<1.2 \mathrm{~g} / \mathrm{kg} \\
\mathrm{n}=68\end{array}$}} & \multirow{2}{*}{\multicolumn{2}{|c|}{$\begin{array}{l}\geq 1.2 \mathrm{~g} / \mathrm{kg} \\
\mathrm{n}=68 \\
\end{array}$}} & \multirow{2}{*}{\multicolumn{2}{|c|}{$\begin{array}{l}\begin{array}{l}\text { All non-septic, } \\
\text { non-overfed patients }\end{array} \\
\mathrm{n}=419\end{array}$}} & \multirow{3}{*}{$\begin{array}{l}\text { Analysis of variance, } \\
\text { Kruskal-Wallis test or chi } \\
\text { squared test, } P \text {-value }\end{array}$} \\
\hline & & & & & & & & & & & \\
\hline & Mean & SD & Mean & SD & Mean & SD & Mean & SD & Mean & SD & \\
\hline Male gender, \% & 66.4 & & 60.0 & & 67.6 & & 61.8 & & 64.9 & & 0.714 \\
\hline Age, y & 63.9 & 16.5 & 61.6 & 16.2 & 62.7 & 15.6 & 62.7 & 17.2 & 63.2 & 16.4 & 0.775 \\
\hline Weight, kg & 78.5 & 17.5 & 79.6 & 15.1 & 80.4 & 17.3 & 75.1 & 14.7 & 78.4 & 16.7 & 0.278 \\
\hline Height, cm & 173 & 9.5 & 173 & 9.2 & 173 & 9.7 & 171 & 10.5 & 173 & 9.6 & 0.556 \\
\hline Body mass index, kg/m2 & 26.2 & 5.3 & 26.9 & 5.6 & 26.8 & 5.5 & 25.6 & 3.7 & 26.3 & 5.2 & 0.439 \\
\hline Body mass index $<18.5, \%$ & 2.7 & & 1.7 & & 0.0 & & 2.9 & & 2.1 & & \\
\hline Body mass index $>30, \%$ & 17.9 & & 21.7 & & 17.6 & & 14.7 & & 17.9 & & \\
\hline APACHE II score & 22.7 & 8.4 & 22.2 & 7.8 & 22.4 & 7.6 & 22.9 & 7.5 & 22.6 & 8.1 & 0.961 \\
\hline Respiratory rate, /minute ${ }^{\mathrm{W}}$ & 20 & 6 & 19 & 6 & 21 & 5 & 22 & 8 & 21 & 7 & 0.059 \\
\hline $\mathrm{VO}_{2}, \mathrm{ml} /$ minute $^{\mathrm{W}}$ & 274 & 64 & 270 & 51 & 286 & 58 & 292 & 55 & 278 & 60 & 0.080 \\
\hline $\mathrm{VCO}_{2}, \mathrm{ml} /$ minute $^{\mathrm{W}}$ & $228^{\mathrm{a}}$ & 54 & $226_{a}$ & 40 & $239^{a, b}$ & 43 & $251^{\mathrm{b}}$ & 53 & 233 & 51 & 0.005 \\
\hline Respiratory quotient ${ }^{\mathrm{W}}$ & 0.84 & 0.10 & 0.85 & 0.12 & 0.85 & 0.10 & 0.86 & 0.08 & 0.84 & 0.10 & 0.436 \\
\hline $\mathrm{FiO}_{2}, \%{ }^{\mathrm{W}, \mathrm{z}}$ & 40 & 40 to 45 & 40 & 40 to 45 & 40 & 40 to 45 & 40 & 40 to 45 & 40 & 40 to 45 & 0.460 \\
\hline Measured $\mathrm{EE}^{\mathrm{x}}, \mathrm{kcal} / \mathrm{d}$ & 1,860 & 367 & 1,864 & 299 & 1,953 & 310 & 1,924 & 348 & 1,886 & 347 & 0.181 \\
\hline Estimated $\mathrm{EE}^{\mathrm{y}}, \mathrm{kcal} / \mathrm{d}$ & 2,049 & 378 & 2,066 & 333 & 2,088 & 365 & 1,993 & 371 & 2,049 & 368 & 0.478 \\
\hline Day-4 energy, kcal/d & $904^{\mathrm{a}}$ & 453 & $1,679^{\mathrm{b}, \mathrm{c}}$ & 256 & $1,840^{c, d}$ & 283 & $1,950^{d}$ & 353 & 1,337 & 608 & $<0.001$ \\
\hline Day-4 intake/measuredEE & $0.49^{\mathrm{a}}$ & 0.25 & $0.91^{b, c}$ & 0.09 & $0.95^{\mathrm{c}, \mathrm{d}}$ & 0.10 & $1.02^{\mathrm{d}}$ & 0.09 & 0.71 & 0.30 & $<0.001$ \\
\hline Day-4 protein, g/kg & $0.35^{\mathrm{a}}$ & 0.24 & $0.86^{\mathrm{b}}$ & 0.06 & $1.05^{\mathrm{c}}$ & 0.05 & $1.30^{\mathrm{d}}$ & 0.10 & 0.69 & 0.43 & $<0.001$ \\
\hline Length of ventilation ${ }^{z}, d$ & 17 & 11 to 29 & 20 & 11 to 28 & 15 & 8 to 27 & 17 & 9 to 24 & 17 & 10 to 28 & 0.128 \\
\hline Length of ICU stay ${ }^{2}, \mathrm{~d}$ & 20 & 13 to 32 & 22 & 13 to 31 & 17 & 9 to 29 & 19 & 10 to 29 & 19 & 12 to 31 & 0.178 \\
\hline Length of hospital stay ${ }^{z}, d$ & 35 & 19 to 60 & 40 & 26 to 63 & 30 & 19 to 61 & 34 & 23 to 49 & 35 & 21 to 59 & 0.447 \\
\hline ICU mortality, \% & 22.0 & & 18.3 & & 17.6 & & 8.8 & & 18.6 & & 0.111 \\
\hline Hospital mortality, \% & 36.8 & & 35.0 & & 26.5 & & 19.1 & & 32.0 & & 0.033 \\
\hline
\end{tabular}

$\mathrm{a}, \mathrm{b}, \mathrm{c}, \mathrm{d}$ Values in the same row not sharing the same letter are significantly different at $P<0.05$ in a post-hoc Bonferroni analysis or pairwise comparison in the analysis of variance or Kruskal-Wallis test WValue at time of energy expenditure measurement. ${ }^{\mathrm{x}}$ Energy target defined by indirect calorimetry. ${ }^{\mathrm{y}}$ Energy target defined by Harris Benedict formula $+30 \%$. ${ }^{\mathrm{N}}$ Non-normally distributed; data presented as median and $25^{\text {th }}$ to $75^{\text {th }}$ percentiles. P-values in bold indicate a significant test result. $\mathrm{APACHE}$, acute physiology and chronic health evaluation; $\mathrm{VO}_{2}$, oxygen uptake; $\mathrm{VCO}_{2}$, carbon dioxide elimination; FiO energy expenditure. 


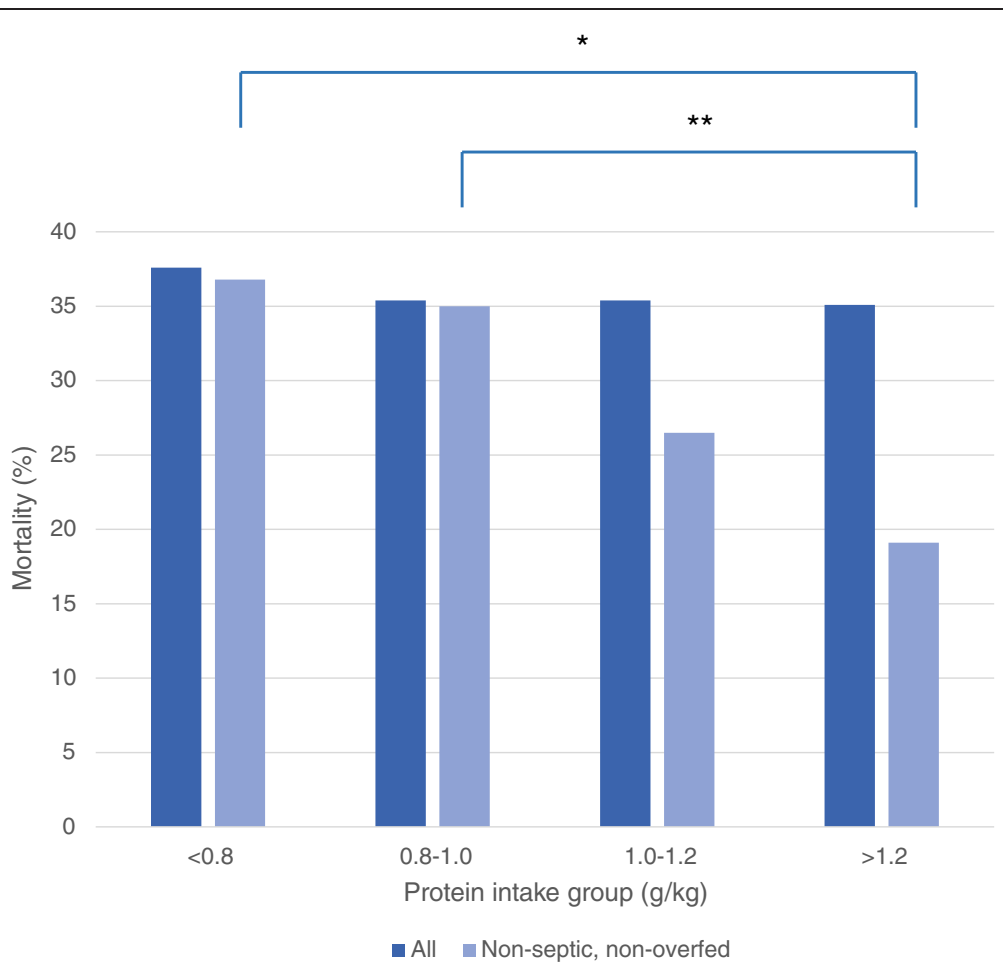

Figure 4 Hospital mortality for all patients per protein intake group and for all non-septic and non-overfed patients per protein intake group. ${ }^{*} P=0.008 ;{ }^{*} P=0.047$.

supports the notion that measuring EE is crucial for optimizing nutrition. Another strong point of this study is that the sample size was large enough to independently assess the effect of protein intake in patients with and without sepsis. Finally, EE was measured while feeding was continued, thereby reflecting real-life total EE.

\section{Conclusion}

The present post-hoc analysis of a prospective observational study shows that early protein intake at a level of $\geq 1.2 \mathrm{~g} / \mathrm{kg}$ at day 4 of ICU admission is associated with lower and early energy overfeeding with higher hospital mortality in critically ill patients with prolonged mechanical ventilation without sepsis. The possible benefit of early high-protein feeding should be confirmed by a randomised controlled trial.

\section{Key messages}

- Early protein intake at a level of $\geq 1.2 \mathrm{~g} / \mathrm{kg}$ at day 4 of ICU admission is associated with lower and early energy overfeeding with higher hospital mortality in non-septic mechanically ventilated critically ill patients.

- In patients with sepsis at admission, no relation was found between early protein intake and mortality.
- In patients with early energy overfeeding, no relation was found between early protein intake and mortality.

\section{Abbreviations}

APACHE: acute physiology and chronic health evaluation; BMI: body mass index; CRRT: continuous renal replacement therapy; EE: energy expenditure; EN: early enteral nutrition; $\mathrm{FiO}_{2}$ : inspired oxygen fraction; $\mathrm{OR}$ : odds ratio; $\mathrm{PN}$ : parenteral nutrition; $\mathrm{VCO}_{2}$ : carbon dioxide elimination; $\mathrm{VO}_{2}$ : oxygen uptake.

\section{Competing interests}

PJMW received funding from Baxter and Nutricia/Danone, not related to this study. Other authors have no conflict of interest to reveal.

\section{Authors contributions}

PW designed the study, obtained the data, performed statistical analysis and drafted the manuscript. WL performed statistical analysis and helped to draft the manuscript. AB obtained the data. AG participated in coordination of the study. $\mathrm{HO}$ participated in coordination of the study and helped to draft the manuscript. All authors read and approved the final manuscript.

\section{Acknowledgements}

We would like to thank Monique de Waard and Ronald Driessen from the VUmc Department of Intensive Care Medicine for their contributions.

\section{Author details}

'Department of Intensive Care Medicine, VU University Medical Center Amsterdam, De Boelelaan 1117, Amsterdam, The Netherlands. ${ }^{2}$ Department of Nutrition and Dietetics, Internal Medicine, VU University Medical Center Amsterdam, De Boelelaan 1117, 1081 HV Amsterdam, The Netherlands. ${ }^{3}$ Department of Nutrition and Dietetics, Amsterdam University of Applied Sciences, Dr. Meurerlaan 8, Amsterdam, The Netherlands. ${ }^{4}$ Institute for Cardiovascular Research, VU University Medical Center Amsterdam, De 
Boelelaan 1117, Amsterdam, The Netherlands. ${ }^{5}$ Department of Intensive Care Medicine, Medisch Spectrum Twente, Haaksbergerstraat 55, Enschede, The Netherlands.

Received: 22 July 2014 Accepted: 27 November 2014

Published online: 14 December 2014

\section{References}

1. Casaer MP, Mesotten D, Hermans G, Wouters PJ, Schetz M, Meyfroidt G, Van Cromphaut S, Ingels C, Meersseman P, Muller J, Vlasselaers D, Debaveye Y, Desmet L, Dubois J, Van Assche A, Vanderheyden S, Wilmer A, Van den Berghe G: Early versus late parenteral nutrition in critically ill adults. N Engl J Med 2011, 365:506 517.

2. Doig GS, Simpson F, Sweetman EA, Finfer SR, Cooper DJ, Heighes PT, Davies AR, O Leary M, Solano T, Peake S: Early parenteral nutrition in critically ill patients with short-term relative contraindications to early enteral nutrition: a randomized controlled trial. JAMA 2013, 309:2130 2138.

3. Arabi YM, Tamim HM, Dhar GS, Al-Dawood A, Al-Sultan M, Sakkijha MH, Kahoul SH, Brits R: Permissive underfeeding and intensive insulin therapy in critically ill patients: a randomized controlled trial. Am J Clin Nutr 2011, 93:569 577

4. Rice TW, Wheeler AP, Thompson BT, Steingrub J, Hite RD, Moss M, Morris A, Dong N, Rock P: Initial trophic vs full enteral feeding in patients with acute lung injury: the EDEN randomized trial. JAMA 2012, 307:795 803 .

5. Fraipont V, Preiser JC: Energy estimation and measurement in critically ill patients. JPEN J Parenter Enteral Nutr 2013, 37:705 713.

6. van Schijndel RJMS, Weijs PJM, Koopmans RH, Sauerwein HP, Beishuizen A, Girbes ARJ: Optimal nutrition during the period of mechanical ventilation decreases mortality in critically ill, long-term acute female patients: a prospective observational cohort study. Crit Care 2009, 13:R132.

7. Weijs PJM, Stapel SN, de Groot SDW, Driessen RH, de Jong E, Girbes ARJ, van Schijndel RJMS, Beishuizen A: Optimal protein and energy nutrition decreases mortality in mechanically ventilated, critically ill patients: a prospective observational cohort study. JPEN J Parenter Enteral Nutr 2012 36:60 68 .

8. Allingstrup MJ, Esmailzadeh N, Wilkens Knudsen A, Espersen K, Hartvig Jensen T, Wiis J, Perner A, Kondrup J: Provision of protein and energy in relation to measured requirements in intensive care patients. Clin Nutr 2012, 31:462 468 .

9. Elke G, Wang M, Weiler N, Day AG, Heyland DK: Close to recommended caloric and protein intake by enteral nutrition is associated with better clinical outcome of critically ill septic patients: secondary analysis of a large international nutrition database. Crit Care 2014, 18:R29.

10. Singer $P$, Hiesmayr M, Biolo G, Felbinger TW, Berger MM, Goeters C, Kondrup J, Wunder C, Pichard C: Pragmatic approach to nutrition in the ICU: expert opinion regarding which calorie protein target. Clin Nutr 2014, 33:246 251.

11. Vanhorebeek I, Gunst J, Derde S, Derese I, Boussemaere M, Guiza F, Martinet W, Timmermans JP, D Hoore A, Wouters PJ, Van den Berghe G: Insufficient activation of autophagy allows cellular damage to accumulate in critically ill patients. J Clin Endocrinol Metab 2011, 96:E633 E645.

12. Casaer MP, Wilmer A, Hermans G, Wouters PJ, Mesotten D, Van den Berghe G: Role of disease and macronutrient dose in the randomized controlled EPaNIC trial: a post hoc analysis. Am J Respir Crit Care Med 2013, 187:247 255.

13. Puthucheary ZA, Rawal J, McPhail M, Connolly B, Ratnayake G, Chan P, Hopkinson NS, Padhke R, Dew T, Sidhu PS, Velloso C, Seymour J, Agley CC, Selby A, Limb M, Edwards LM, Smith K, Rowlerson A, Rennie MJ, Moxham J, Harridge SDR, Hart N, Montgomery HE: Acute skeletal muscle wasting in critical illness. JAMA 2013, 310:1591 1600

14. Derde S, Vanhorebeek I, Guiza F, Derese I, Gunst J, Fahrenkrog B, Martinet W, Vervenne H, Ververs EJ, Larsson L, Van den Berghe G: Early parenteral nutrition evokes a phenotype of autophagy deficiency in liver and skeletal muscle of critically ill rabbits. Endocrinology 2012, 153:2267 2276.

15. Choi AJ, Ryter SW: Autophagy in inflammatory diseases. Int J cell biol 2011, 2011:732798.

16. van Schijndel RJM S, Weijs PJM, Sauerwein HP, de Groot SDW, Beishuizen A, Girbes ARJ: An algorithm for balanced protein/energy provision in critically ill mechanically ventilated patients. e-SPEN, Eur e-J Clin Nut Metab 2007, 2:69 74
17. Singer $P$, Berger MM, Van den Berghe $G$, Biolo $G$, Calder P, Forbes A, Griffiths $R$, Kreyman G, Leverve X, Pichard C, ESPEN: ESPEN Guidelines on Parenteral Nutrition: intensive care. Clin Nutr 2009, 28:387 400

18. Compher C, Frankenfield D, Keim N, Roth-Yousey L: Best practice methods to apply to measurement of resting metabolic rate in adults: a systematic review. J Am Diet Assoc 2006, 106:881 903.

19. Weijs PJM, Sauerwein HP, Kondrup J: Protein recommendations in the ICU: $\mathrm{g}$ protein/kg body weight - which body weight for underweight and obese patients? Clin Nutr 2012, 31:774 775 .

20. van Schijndel RJMS, de Groot SDW, Driessen RH, Ligthart-Melis G, Girbes ARJ, Beishuizen A, Weijs PJM: Computer-aided support improves early and adequate delivery of nutrients in the ICU. Neth J Med 2009, 67:388 393.

21. Dellinger RP, Carlet JM, Masur H, Gerlach H, Calandra T, Cohen J, Gea-Banacloche J, Keh D, Marshall JC, Parker MM, Ramsay G, Zimmerman JL, Vincent JL, Levy MM: Surviving Sepsis Campaign guidelines for management of severe sepsis and septic shock. Critical care medicine 2004, 32:858 873.

22. Dellinger RP, Levy MM, Carlet JM, Bion J, Parker MM, Jaeschke R, Reinhart K, Angus DC, Brun-Buisson C, Beale R, Calandra T, Dhainaut JF, Gerlach H, Harvey M, Marini JJ, Marshall J, Ranieri M, Ramsay G, Sevransky J, Thompson BT, Townsend S, Vender JS, Zimmerman JL, Vincent JL: Surviving Sepsis Campaign: international guidelines for management of severe sepsis and septic shock: 2008. Intensive care medicine 2008, 34:17 60.

23. Masiero E, Agatea L, Mammucari C, Blaauw B, Loro E, Komatsu M, Metzger D, Reggiani C, Schiaffino S, Sandri M: Autophagy is required to maintain muscle mass. Cell Metab 2009, 10:507 515

24. Hermans G, Casaer MP, Clerckx B, Guiza F, Vanhullebusch T, Derde S, Meersseman P, Derese I, Mesotten D, Wouters PJ, Van Cromphaut S, Debaveye Y, Gosselink R, Gunst J, Wilmer A, Van den Berghe G, Vanhorebeek I: Effect of tolerating macronutrient deficit on the development of intensive-care unit acquired weakness: a subanalysis of the EPaNIC trial. The lancet Respiratory medicine 2013, 1:621 629.

25. Virgin HW, Levine B: Autophagy genes in immunity. Nat Immunol 2009 10:461 470 .

26. Klaude M, Mori M, Tjader I, Gustafsson T, Wernerman J, Rooyackers O: Protein metabolism and gene expression in skeletal muscle of critically ill patients with sepsis. Clin Sci(Lond) 2012, 122:133 142.

27. Heidegger CP, Berger MM, Graf S, Zingg W, Darmon P, Costanza MC, Thibault R, Pichard C: Optimisation of energy provision with supplemental parenteral nutrition in critically ill patients: a randomised controlled clinical trial. Lancet 2013, 381:385 393.

28. Savard JF, Faisy C, Lerolle N, Guerot E, Diehl JL, Fagon JY: Validation of a predictive method for an accurate assessment of resting energy expenditure in medical mechanically ventilated patients. Crit Care Med 2008, 36:1175 1183

29. Faisy C, Guerot E, Diehl JL, Labrousse J, Fagon JY: Assessment of resting energy expenditure in mechanically ventilated patients. Am J Clin Nut 2003, 78:241 249.

30. Frankenfield D, Smith JS, Cooney RN: Validation of 2 approaches to predicting resting metabolic rate in critically ill patients. JPEN J Parenter Enteral Nutr 2004, 28:259 264.

31. Singer $P$, Anbar R, Cohen J, Shapiro H, Shalita-Chesner M, Lev S, Grozovski E, Theilla M, Frishman S, Madar Z: The tight calorie control study (TICACOS): a prospective, randomized, controlled pilot study of nutritional support in critically ill patients. Intensive Care Med 2011, 37:601 609.

32. Weijs PJM, Wischmeyer PE: Optimizing energy and protein balance in the ICU. Curr Opin Clin Nutr Metab Care 2013, 16:194 201

\section{doi:10.1186/s13054-014-0701-z}

Cite this article as: Weijs et al:: Early high protein intake is associated with low mortality and energy overfeeding with high mortality in non-septic mechanically ventilated critically ill patients. Critical Care 2014 18:701. 